\title{
Afterlife Writing and Situation of Graves II
}

\author{
Jane Wildgoose
}

King's College London

\section{ABSTRACT}

This article discusses my practice as an artist and researcher examining the situation and significance of graves. First, in a site-specific installation at West Norwood Cemetery in South London, talking with visitors about whether it matters where human remains are deposited; secondly, in exhibitions at the Crypt Gallery St. Pancras and Lumen Crypt Gallery in Bethnal Green, presenting evidence of the historical circumstances in which human remains were appropriated from graves in the colonies, for the purposes of research into racial 'science' in museums during the late nineteenth century.

Keywords: archive, grave, craniology, museum

\section{SITUATION OF GRAVES}

In their study of over one thousand long-term visitors to London graveyards today, Doris Francis et al. demonstrate that

\footnotetext{
men, women and children of all ages, religions, ethnicities and income levels visit cemeteries [...] During these visits they [may] tend the grave, clean the memorial stone, arrange flowers, talk with the deceased and with other visitors, and reflect on profound issues. ${ }^{1}$
}

Francis et al. conclude that 'old cemeteries encourage the living to examine the meaning of the ancestral past, and they summon the present 
generation to honour its contract and connections with the past dead and those yet to be born'. ${ }^{2}$ Overall, Francis $e t$ al. 'emphasize the importance cemetery visitors' they interviewed 'attached to the presence of the body both in the ground in a particular place and as "embodied" in the memorial stone and sometimes the grave garden'. ${ }^{3}$

The significance of the situation of graves and their importance to individual and collective memory has been a central theme in my practice as an artist and researcher for many years. In 2013, I had the opportunity to raise some questions on these themes site-specifically, in one of London's ‘Magnificent Seven’ Victorian cemeteries, when I was invited by the curator Jane Millar to exhibit my work at West Norwood Cemetery in South London as part of an art-trail presenting the work of 22 contemporary artists. ${ }^{4}$ I set up a temporary outpost of my collection, The Wildgoose Memorial Library, in the light-filled marble and mosaic-lined interior of the mausoleum of Dr. Edmund Distin Maddick (1857-1939), ${ }^{5}$ taking as my starting point Ken Worpole's 'idea that burial places and cemeteries also function as libraries of past lives, beliefs and artefacts, able to be read again and again by succeeding generations'. ${ }^{6}$ (http://www.mmtrust. org.uk/mausolea/view/288/Maddick_Mausoleum)

Exploring Worpole's suggestion that, 'like libraries, cemeteries are quiet, catalogued and annotated', I began by photographing the Burial Registers at West Norwood which, as a legal requirement, date back in an unbroken record to 1837 when the cemetery first opened. ${ }^{7}$ The Registers literally constitute an 'archive' of the record of the dead-a library of aged leather-bound registers and modern lever arch files stored in two large fireproof safes documenting the names, dates and places of interment of both bodies and ashes. ${ }^{8}$ The archive is kept in the reception area of the Cemetery, which doubles as the Bereavement Services staff office. During the day that I spent photographing the Registers, I was able to observe the extent to which these records serve as a well-used and valued resource-as indicated by the worn and repaired condition of the older volumes (Figs. 1 and 2).

The staff responded to a steady stream of enquiries from members of the public (ranging from historians to family members) telephoning and visiting to ask about the situation of the graves, dating from the nineteenth and twentieth centuries to the present. They spoke eloquently to me about the value they perceived in maintaining a functioning nineteenth-century cemetery, and the part that the archive of burials plays in locating graves in the twenty-first century. If I had been in any doubt before, it became clear to me at West Norwood Cemetery that, for its visitors, this place of the dead is vital-a living illustration of Robert Pogue Harrison's contention that 'humans bury not simply to achieve closure 


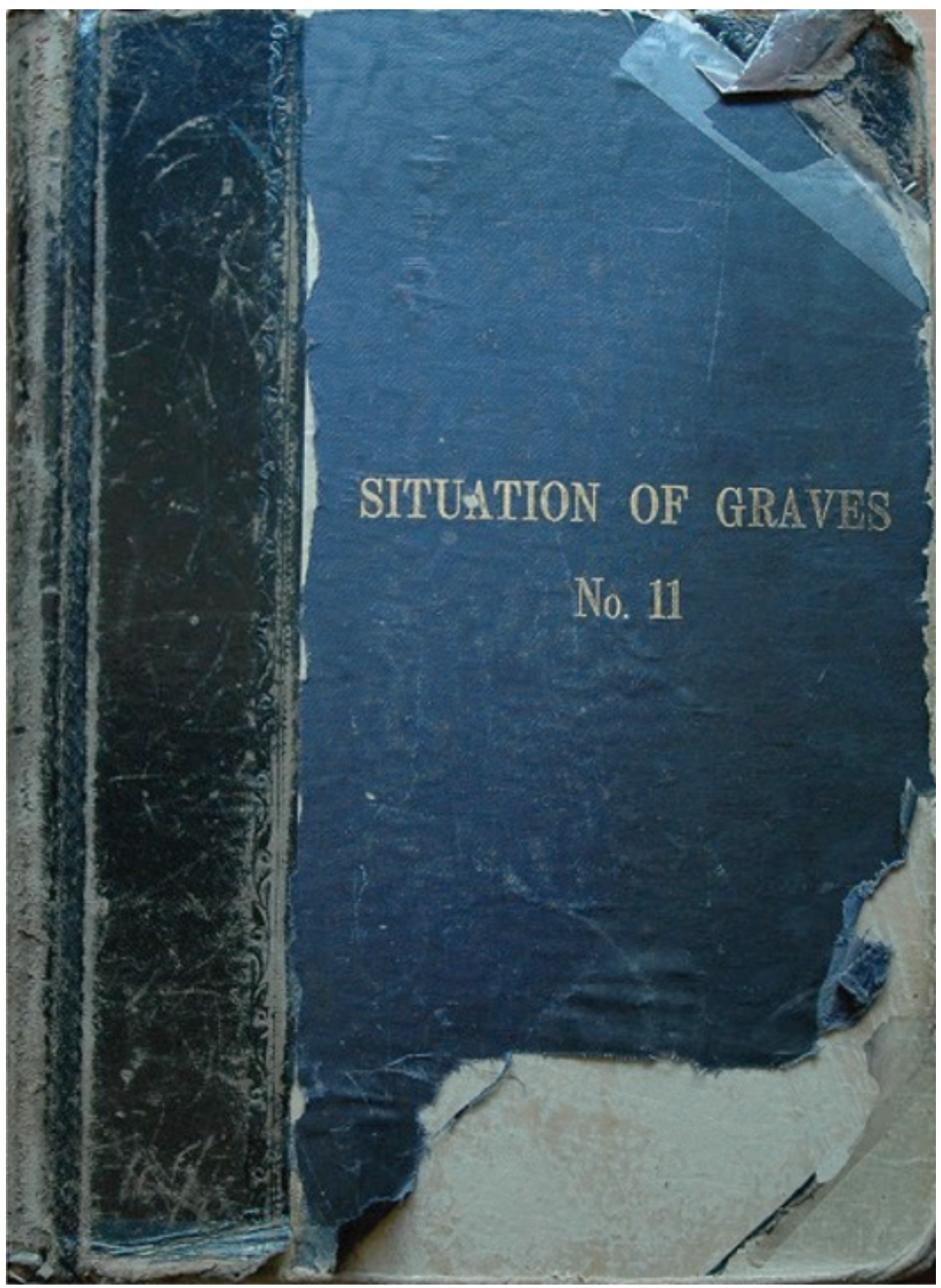

Fig. 1 Situation of Graves No. 11, 2013.

(C) Jane Wildgoose, The Wildgoose Memorial Library. 


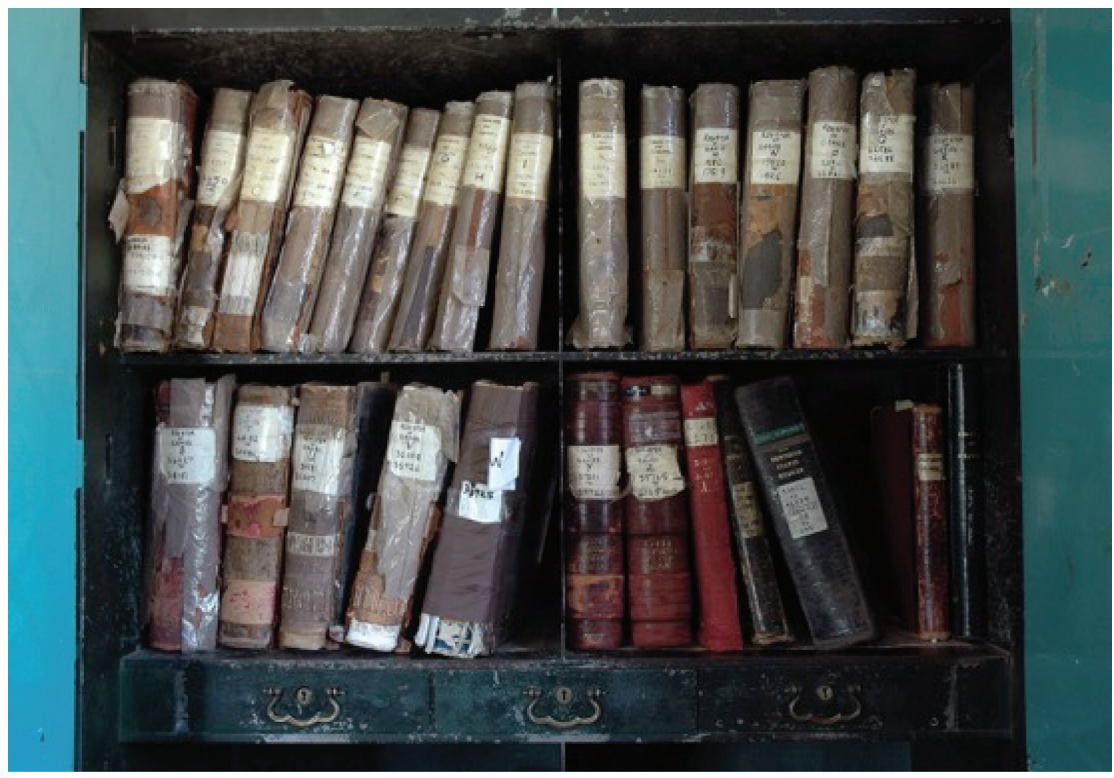

Fig. 2 Burial Registers, West Norwood Cemetery, 2013.

(c) Jane Wildgoose, The Wildgoose Memorial Library.

and effect a separation from the dead but also and above all to humanize the ground on which they build their worlds and found their histories'.

At West Norwood, I was able to give some consideration to the columbarium, where receptacles containing ashes are deposited in an indexed shelving system, which is reminiscent of the organisation of an archive (Fig. 3). I also had the opportunity to compare this formal arrangement with the more informal, but nonetheless very deliberate, grouping of objects and flowers left as offerings, which surely constitute a kind of dialogue with the dead. These regularly refreshed tributes provided a dynamic material reminder that, as Mark C. Taylor argues, 'the graveyard is the place where we keep the dead alive as dead'-it is a place that answers a significant need on the part of the living: to visit the named dead in a known situation as part of necessary processes of establishing and maintaining personal, familial, and cultural identity, continuity, life writing and storytelling. ${ }^{10}$

I would have the opportunity to test these ideas with the public when I exhibited selected objects and books from The Wildgoose Memorial Library collection, together with my photographs of the Burial Registers and selected materials from an assemblage of obsolete items from the 


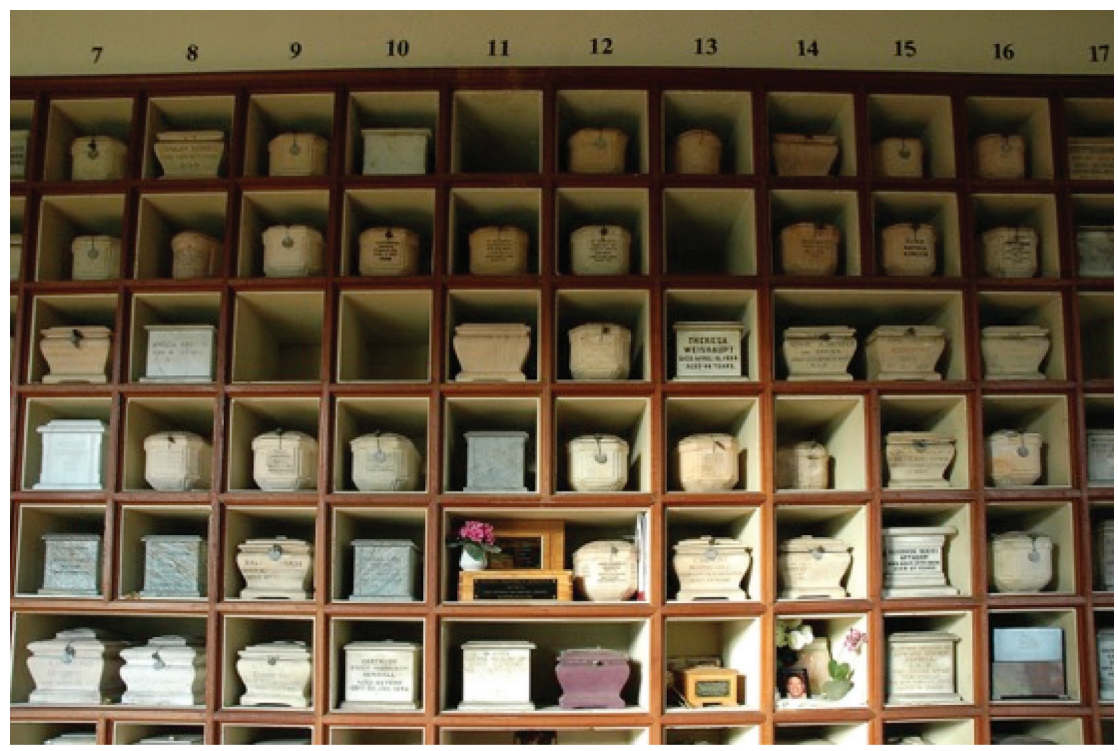

Fig. 3 Columbarium, West Norwood Cemetery, 2013.

(C) Jane Wildgoose, The Wildgoose Memorial Library.

Cemetery (preserved by one of its managers), in the Maddick Mausoleum. At the centre of the installation, I presented a broken and re-embellished antique 'immortelle' wreath of glass-beaded flowers from my collection, of the type traditionally left on graves in France. ${ }^{11} \mathrm{I}$ was present in the installation as Keeper of The Wildgoose Memorial Library on a number of days during the exhibition, and this provided the opportunity to speak with visitors. I asked them whether they thought it mattered where human remains were deposited? I also asked them did they care? If they did-and no one I spoke to said that they did not care, while many evidently cared very much-then I invited them to write the name of someone significant to them who had died, together with the place of interment or where their ashes were scattered, on printed cards (based on a Victorian mourning card in my collection) which were added to the wreath (Fig. 4).

Some of the self-selecting group of people who contributed to this exercise knew of and still visited the family grave of ancestors buried in West Norwood Cemetery, who had died over one hundred years ago. Some respondents knew the situation of the graves so well that they included their numbers on the card: 


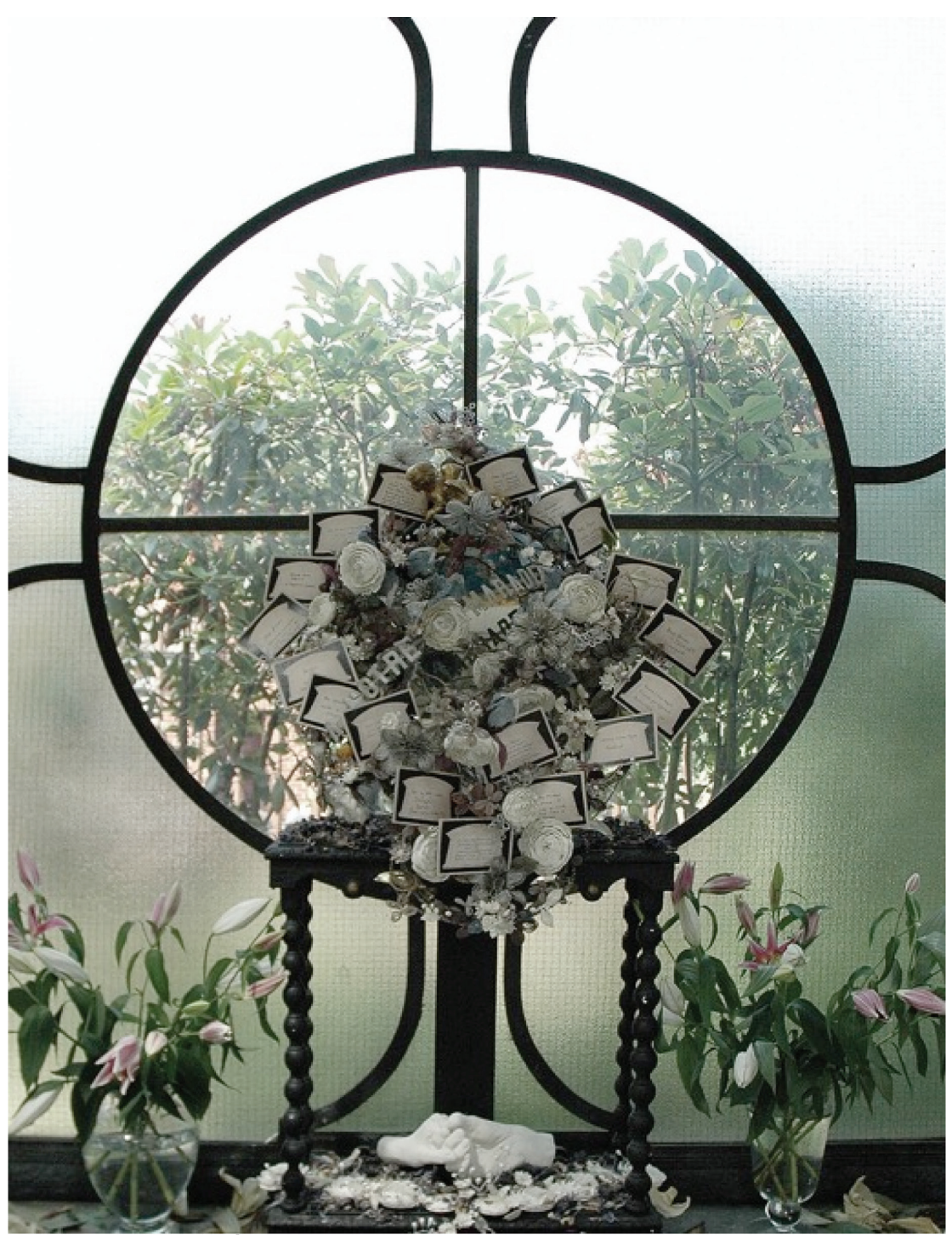

Fig. 4 Immortelle: À Notre Camarade, in A Question of Archival Authority, 2013. West Norwood Cemetery. (C) Jane Wildgoose, The Wildgoose Memorial Library. 
No 3034135081 In loving memory James Wimshusrt son of Henry Wimshurst Born $13^{\text {th }}$ April 1832 Died $3^{\text {rd }}$ January 1903

$4 \times$ Grandfather-Michael L--

On the reverse of the card, these respondents (a family) had written clues to the lives of the dead they were visiting, as well as the place where they were interred:

West Norwood Cemetery

James Wimshurst Inventor-Wimshurst Machine

Henry-Ship Builder inventor-corkscrew propeller

Next to Grave no 30270

Some visitors knew of and visited the graves of nineteenth-century celebrities: for instance, 'Mrs. Beeton West Norwood A Good Cook'. Others recorded relatives or friends whose bodies were buried, or ashes scattered, elsewhere. The situation was clearly significant to the visitors who contributed to the wreath. One card includes the name of a woman with the place recorded as 'in the city she loved-Budapest'; another details three different and very specific places where a man's ashes were scattered: 'in the River Thames at Henley Regatta. In the Bay in Moreara and under the lemon tree in the garden Spain'. Many visitors felt the need to go beyond the simple request I had made-that they write the name of someone significant to them who had died and their place of rest-and felt compelled to add a message about (or to) the dead. Overall, it was clear that respondents felt a strong sense of communication with the dead, with the significance of the site where their remains had been deposited and its connection with the stories of their lives (Fig. 5).

On one card 'my mother Josephine' was recorded and the place given as 'I still have a lock of her hair in my purse'. Another named 'Charles Byrne (THE IRISH GIANT)'-whose body was acquired against his expressed wishes during the eighteenth century by the surgeon John Hunter for his museum, which is now known as the Hunterian Museum of the Royal College of Surgeons of England. ${ }^{12}$ The place recorded was 'the HUNTERIAN MUSEUM', together with the comment '(but should not be there)'. This card was signed by the Director of the Irish Chaplaincy in Britain, who was involved in a campaign for the return of Byrne's skeleton to Ireland for burial.

The records on these last two cards were of special relevance to my line of enquiry, as my work at West Norwood Cemetery formed part of a larger project in which I was developing an artist's response to the Department for Culture, Media and Sport's Guidance for the Care of Human Remains in Museums (2005). ${ }^{13}$ The Guidance ascribes a 'unique status' to human 


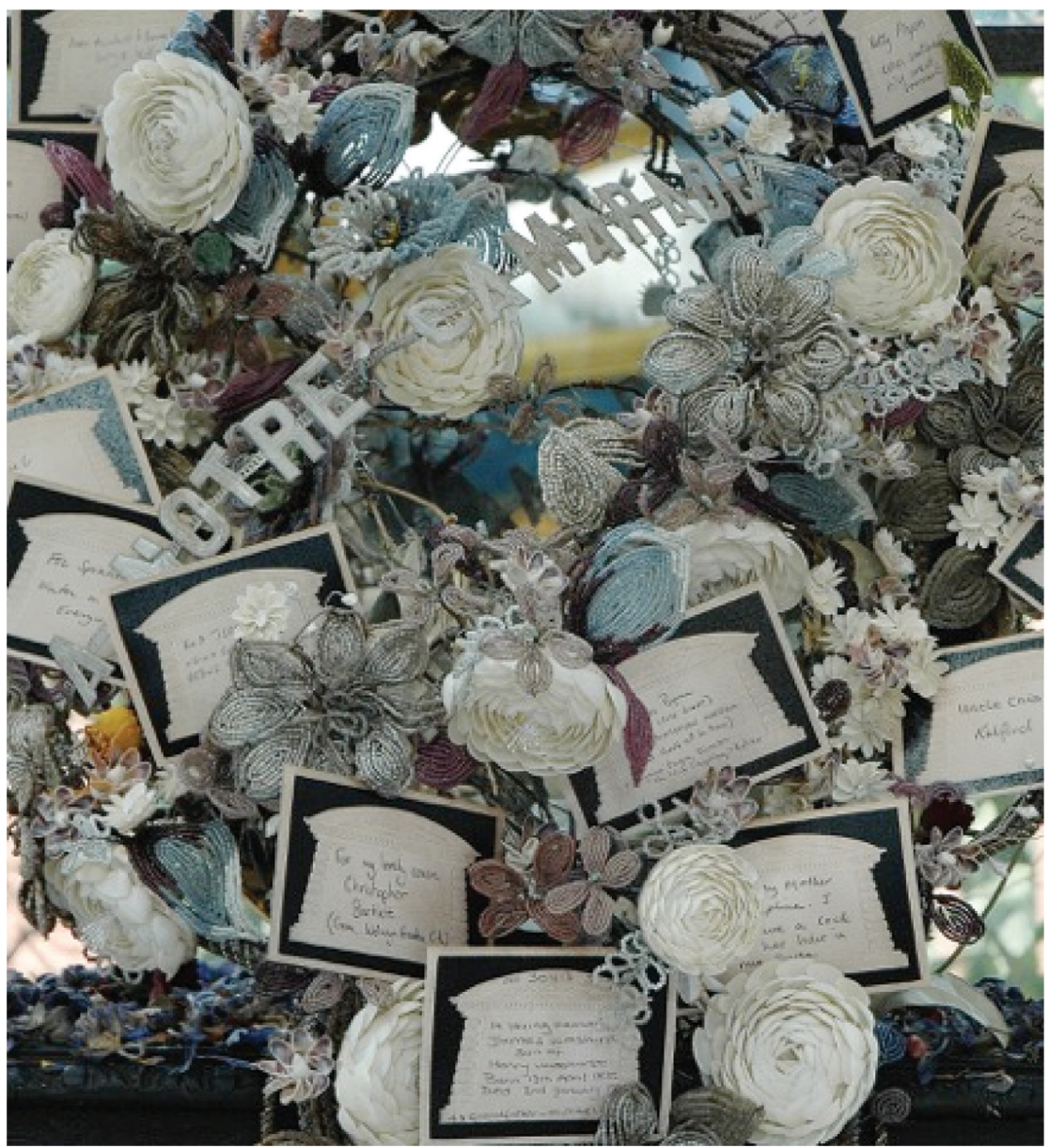

Fig. 5 Immortelle: À Notre Camarade, detail, 2013.

West Norwood Cemetery @ Jane Wildgoose, The Wildgoose Memorial Library.

remains in museums, and was published to accompany a change to the $\mathrm{law}^{14}$ in response to claims from Indigenous peoples for the return of their ancestors' remains from collections in the UK. ${ }^{15}$ As part of this research, I was investigating the background to a statement in the Guidance that 'some human remains [...] were acquired' for museums 'between 100 and 200 years ago from Indigenous peoples in colonial circumstances, where there was a very uneven divide of power'. I was also exploring the 'unique status' the Guidance ascribes to human remains: as objects used for 
research, teaching and display-which may equally be perceived as $s u b$ jects, with 'personal, cultural, symbolic, spiritual or religious significance to individuals and, or, groups. ${ }^{16}$

In my response to the DCMS Guidance, I would use my role as Keeper of The Wildgoose Memorial Library as a lens, through which we can view the historical circumstances that have led to human remains in collections being ascribed their 'unique status'. My research included transcribing parts of a substantial archive of unpublished nineteenth-century correspondence from an extensive network of suppliers of human skulls (collected in great quantity and generally without consent from recent and ancient graves, from hospital mortuaries, battlefields and execution places in the colonies) in order to provide data for hierarchical theories of the so-called 'races of mankind'. ${ }^{17}$ Presenting my findings as a comparative study, I would draw a contrast between the scientific objectification of human remains for the purposes of racial 'science' in museums, during the Victorian colonial era, and the ways in which (in wider society at that time) human hair was popularly used as a subject of commemoration in mourning jewellery and other commemorative artefacts.

In order to learn more about the ways in which human hair was used as a material of mourning, I visited Leila's Hair Museum in Independence Missouri, USA, where I learnt the techniques used by nineteenthcentury amateur women hairworkers, who made wreaths from the hair of family and friends. ${ }^{18}$ As cultural historian Helen Sheumaker explains, in making these wreaths-in which each flower was crafted from the hair of a known individual-the women makers bound together lasting and tangible records of networks of significant "personal relationships and emotion', making manifest the otherwise invisible threads binding together family groups, friends, and others with common sympathies and loyalties. ${ }^{19}$ Following the example of the nineteenth-century makers, I would go on to develop my own commemorative wreath for the twentyfirst century, made from donated human hair. Each flower in the wreath (which is entitled Lost But Not Forgotten, and mounted on a convex mirror) commemorates the life of an individual whose skull was taken from the colonies for the purpose of providing data for racial 'science' in a metropolitan museum during the period of Victorian colonial rule in the nineteenth century (Fig. 8).

In 2014, I presented my findings as an archive of The Wildgoose Memorial Library at the Crypt Gallery St Pancras-a contemporary art gallery that doubles as the last resting place of the 'honour'd dust' of 557 local parishioners interred there from 1822 to 1854 -and in 2018, at the Lumen Crypt Gallery at St John on Bethnal Green. ${ }^{20}$ The Lost But Not Forgotten wreath was displayed at the heart of the archive, alongside 
my transcriptions from the letters from suppliers of human skulls from the colonies and excerpts from the published catalogues, which accompanied the comparative anatomical collection of which they became part. Also included in the archive were quotations from diaries and hairworkers' manuals and hard copies of the DCMS Guidance for the Care of Human Remains in Museums (2005) and the United Nations Declaration of the Rights of Indigenous Peoples (2008) - the latter identifying the rights of Indigenous peoples 'to maintain, protect, and have access in privacy to their religious and cultural sites; the right to use and control of their ceremonial objects; and the right to the repatriation of their human remains (my italics J.W.)' ${ }^{21}$ (Fig. 6).

The site-specific settings-which, at St Pancras, retain numerous objects related to the commemoration of the dead, including plaques identifying family vaults, and a series of nineteenth-century gravestones with names and dates of birth and death engraved on them-were selected as situations in which to reflect upon afterlife writing, and the ethical dimension of addressing claims from Indigenous peoples for the repatriation of their ancestors' remains from museums. In these settings, the questions raised about contested human remains resonated within

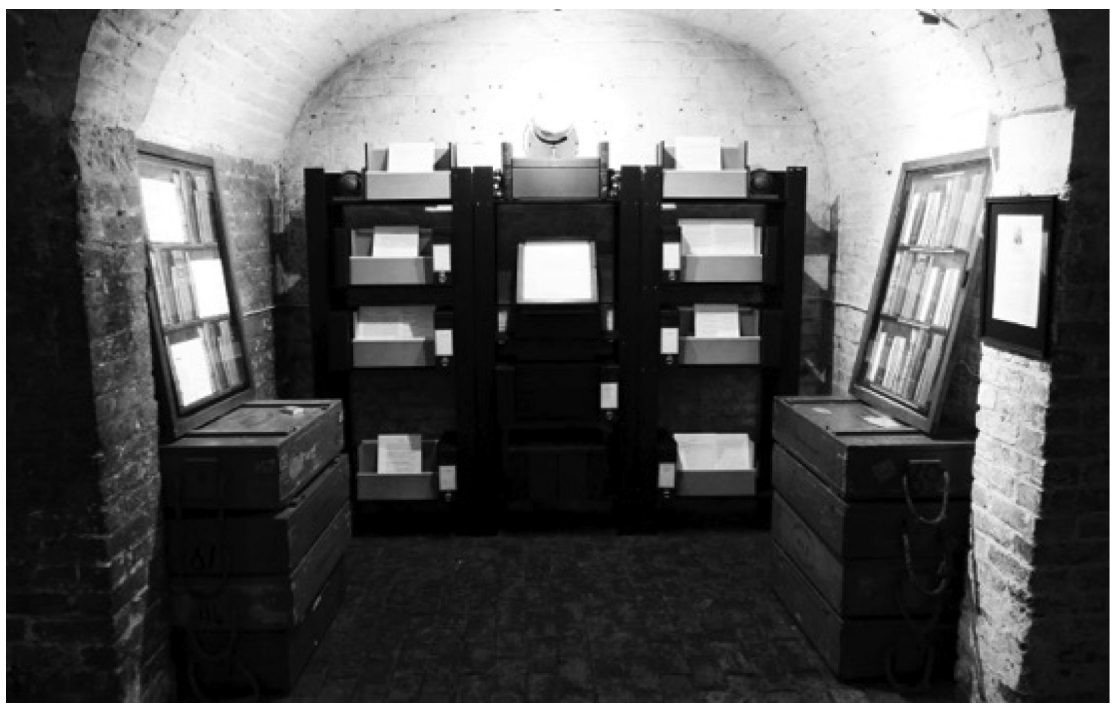

Fig. 6 Lost But Not Forgotten archive in Passing Fables \& Comparative Readings at The Wildgoose Memorial Library: Collecting \& Interpreting Human Skulls \& Hair in Late $19^{\text {th }}$ Century London, Crypt Gallery St Pancras, 2014 (C) Jane Wildgoose, The Wildgoose Memorial Library. 


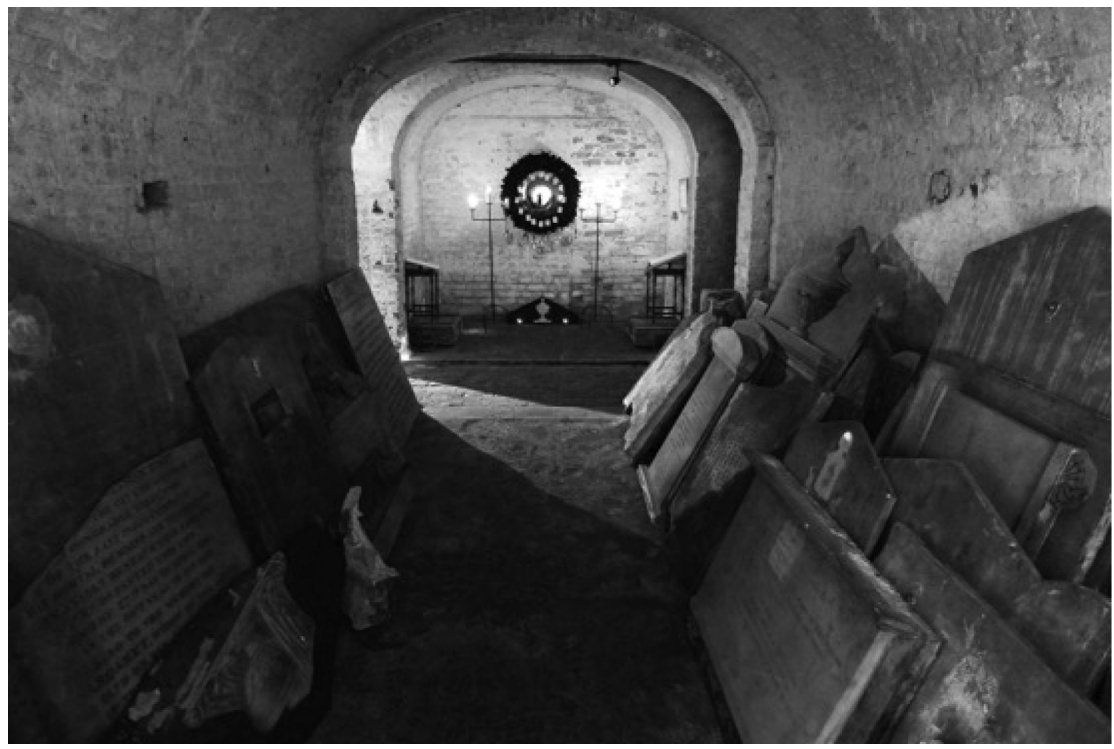

Fig. 7 Lost But Not Forgotten wreath, in Passing Fables \& Comparative Readings at The Wildgoose Memorial Library: Collecting \& Interpreting Human Skulls \& Hair in Late $19^{\text {th }}$ Century London, Crypt Gallery St Pancras, 2014 (C) Jane Wildgoose, The Wildgoose Memorial Library.

the 'active presence' exerted by a burial site-especially when it is 'full of names, biographical details, icons and epitaphs', which 'have the effect of endorsing the notion that they truly do function as libraries in stone ${ }^{22}$ (Fig. 7).

At the Crypt galleries, visitors made thoughtful responses to the archive, and to the questions it raised about the situation of graves and the status of contested human remains in museum collections today. One visitor emailed me saying, 'What an inspired choice of place [...] you have transformed it into a LIBRARY a gallery, and a thinking space full of beautiful and brutal words and ideas' - the 'brutal words' being a reference to the nineteenth-century correspondence from the suppliers, who procured human skulls for the purposes of racial 'science' in museums from peoples whose lands had been occupied by force. ${ }^{23}$

Another visitor wrote a letter commenting on 'the smell, the dampness, the salt, the dark chambers and the enlightened chambers' of the crypt setting. She added that, 'the below-ground experience is an emotional as well as a sensory one [...] these factors induce new patterns of thinking and potential understanding through the body'. ${ }^{24}$ Another emailed saying, 'You are illuminating a 


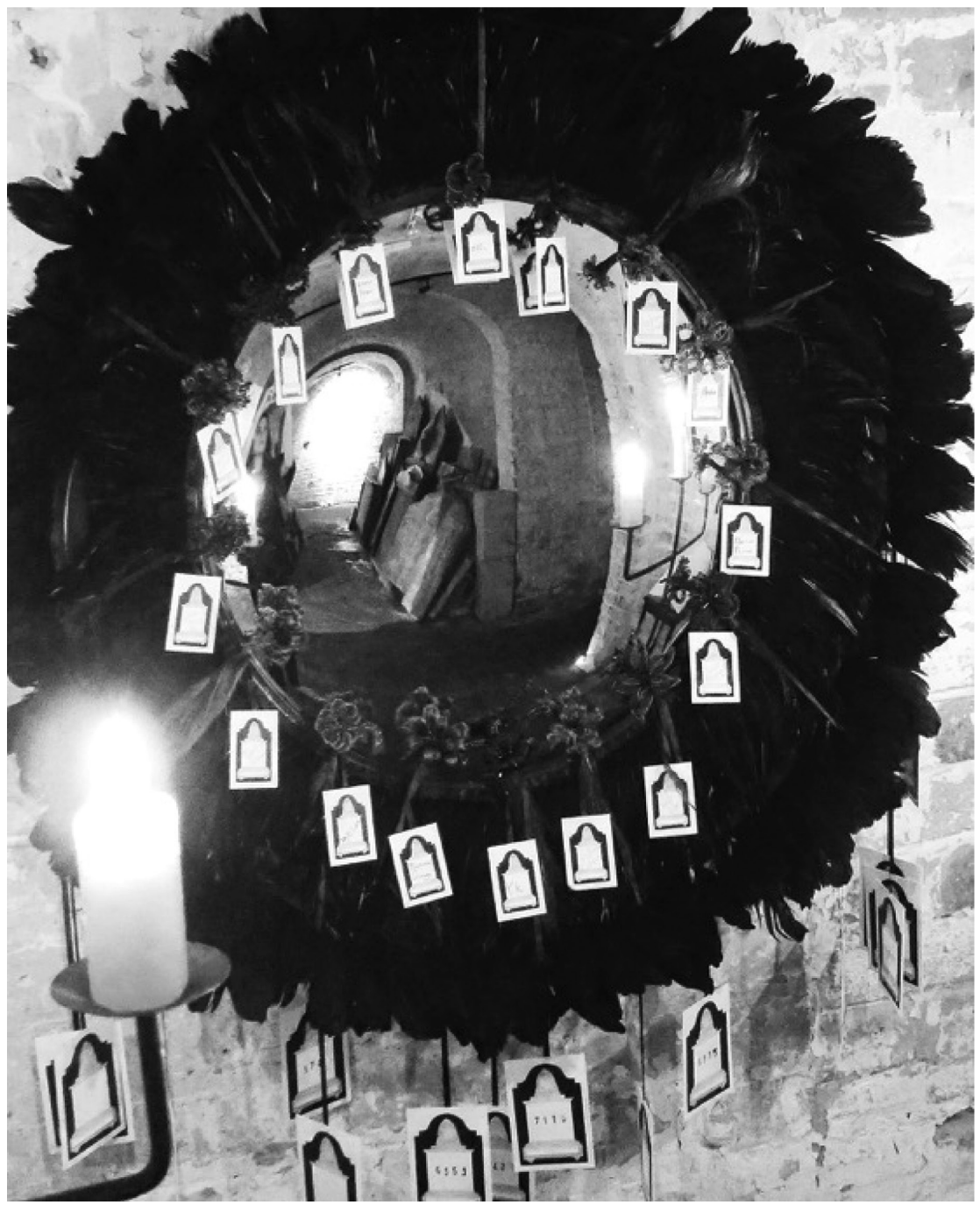

Fig. 8 Lost But Not Forgotten wreath, in Passing Fables \& Comparative Readings at The Wildgoose Memorial Library: Collecting \& Interpreting Human Skulls \& Hair in Late $19^{\text {th }}$ Century London, Crypt Gallery St Pancras, 2014 (C) Jane Wildgoose, The Wildgoose Memorial Library.

most important discussion', adding, '[w] ere I not entering these dreamlike chambers-could I find the psychic space to encompass the moral dilemma? ${ }^{25}$ 
The important discussion that was raised at the Crypt galleries has been going on for many years, both nationally and internationally, within the museum sector and in the claims made by Indigenous peoples for return of their ancestors' remains, as well as in the academy. ${ }^{26}$ Yet, as I have learnt from conversations during my research and in my exhibitions, few museum-goers in the UK know much about the circumstances in which human remains were acquired during the colonial past, or have the opportunity to think in an informed way about the implications of the context in which they are held in collections today. ${ }^{27}$ By placing the evidence I have gathered within 'the place [...] in our midst where the dead exert their power, press their demands, grant or deny their blessing, become loquacious, and in general co-habit our worlds', ${ }^{28}$ it is my aim to bring our ready understanding of the places of the dead, and the situation of graves in Western culture, to bear on the consideration of the claims of Indigenous peoples to their ancestors' remains in museums. And to remember-equally-when we discuss Hogarth's tomb, or enter a Victorian crypt with a sense of reverence and self-reflection, or read about a claim for contested ancestral remains from a museum, that 'humans bury not simply to achieve closure and effect a separation from the dead but also and above all to humanize the ground on which they build their worlds and found their histories' ${ }^{29}$

\section{WORKS CITED}

Brown, Pete. 'Us and Them: Who Benefits from Experimental Exhibition Making?' Museum Management and Curatorship 26:2 (May 2011) 129-148.

Catalogue of the Contents of the Museum of the Royal College of Surgeons in London. Part III. Comprehending the Human Comparative Anatomy. London: Francis Ware, 1831.

Culture24. 'Exhibition preview: Curious-A Site-Specific Art Trail in West Norwood Cemetery, West Norwood Cemetery, London, until July 28 2013.' 26 June 2013, https://www. culture24.org.uk/art/art441080.

Department for Constitutional Affairs (DCA). Guide for Burial Ground Managers. London: DCA, 2005.

Department for Culture, Media and Sport (DCMS). Guidance for the Care of Human Remains in Museums. London: DCMS, 2005.

Doelp, Carol Benner. The Art of French Beaded Flowers: Creative Techniques for Making 30 Beautiful Blooms. New York: Lark Books, 2005.

Douglas, Bronwen and Chris Ballard (eds.). Foreign Bodies: Oceania and the Science of Race 1750-1940. Canberra: Australian National University E. Press, 2008.

Dumont, Clayton Jnr. 'Dead Family or Archaeological Collections? On the Significance of Native Dead.’ Race, Gender Eं Class 9:2 (2002) 8-31.

Francis, Doris, Leonie Kellaher and Georgina Neophytou. The Secret Cemetery. Oxford \& New York: Berg, 2005.

Harrison, Robert Pogue. The Dominion of the Dead. Chicago: University of Chicago Press, 2003.

Human Tissue Act 2004 Chapter 30: Section 47. Power to De-Accession Human Remains. London: HMSO, 2004, 29-30. 
Jenkins, Tiffany. "Who are we to Decide?" Internal Challenges to Cultural Authority in the Contestation over Human Remains in British Museums.' Cultural Sociology 6:4 (July 2012) 455-470, published online 12 July 2012, http://cus.sagepub.com/content/ early/2012/05/15/1749975512445432.

Jenkins, Tiffany. Contesting Human Remains in Museum Collections: The Crisis of Cultural Authority. New York \& Abingdon: Routledge, 2014.

Nathanson, Virginia. The Art of Making Bead Flowers and Bouquets. New York: Hearthside Press, 1967.

Pickering, Michael and Phil Gordon. 'Repatriation: the End of the Beginning.' In: Des Griffin and Leon Paroissien (eds.). Understanding Museums: Australian Museums and Museology. Canberra: National Museum of Australia, 2011, https://nma.gov.au/research/ understanding-museums/MPickering_PGordon_2011.html, ISBN 978-1-876944-92-6.

Sheumaker, Helen. Love Entwined: The Curious History of Hairwork in America. Philadelphia: University of Pennsylvania Press, 2007.

Taylor, Mark C. and Dietrich Christian Lammerts. Grave Matters. London: Reaktion Books, 2002.

The Mausolea \& Monuments Trust. 'Maddick Mausoleum,' http://www.mmtrust.org.uk/ mausolea/view/288/Maddick_Mausoleum.

United Nations. 'United Nations Declaration on the Rights of Indigenous Peoples.' United Nations Department of Social and Economic Affairs: Indigenous Peoples, March 2008, Article 12.1, 6, https://www.un.org/development/desa/indigenouspeoples/declarationon-the-rights-of-indigenous-peoples.html.

Wildgoose, Jane. 'About the Library.' The Wildgoose Memorial Library, http://www.janewildgoose.co.uk/about_the_library.html.

Wildgoose, Jane. 'Collecting and Interpreting Human Skulls and Hair in Late NineteenthCentury London: Passing Fables $\mathcal{E}$ Comparative Readings at The Wildgoose Memorial Library; An artist's response to the DCMS Guidance for the Care of Human Remains in Museums (2005).' PhD diss., Kingston University London, 2015.

Wildgoose, Jane. "Ways of Making with Human Hair and Knowing How to "Listen" to the Dead.' West $86^{\text {th }}$ : A Journal of Decorative Arts, Design History and Material Culture 23:1 (Spring/Summer 2016) 79-101.

Wildgoose, Jane. 'Post-Specimens and Present Ancestors: Passing Fables and Comparative Readings at The Wildgoose Memorial Library-An Artist's Response to the Status of Postcolonial Human Remains in Museums.' In: Edward Juler and Alistair Robinson (eds.), Post-Specimen: Interobjective Encounters in Art, Science and Museology. Bristol: Intellect Books, forthcoming, 2020.

Worpole, Ken. Last Landscapes: The Architecture of the Cemetery in the West. London: Reaktion Books, 2003.

https://www.culture24.org.uk/art/art441080.

https://nma.gov.au/research/understanding-museums/MPickering_PGordon_2011. html, ISBN 978-1-876944-92-6.

http://www.mmtrust.org.uk/mausolea/view/288/Maddick_Mausoleum.

https://www.un.org/development/desa/indigenouspeoples/declarationon-the-rights-ofindigenous-peoples.html.

http://www.janewildgoose.co.uk/about_the_library.html.

\section{ABOUT THE AUTHOR}

Dr Jane Wildgoose is an artist and researcher and Visiting Senior Research Fellow in the Centre for Life-Writing Research at King's College London. 
Her practice centres on collecting, memory and remembrance. She works to commission with museums and has exhibited at Kensington Palace (Historic Royal Palaces), Waddesdon Manor (Rothschild Collections/ National Trust) and Sir John Soane's Museum in the UK and the Yale Center for British Art in the USA. Her recent publications include 'PostSpecimens and Present Ancestors: Passing Fables E Comparative Readings at The Wildgoose Memorial Library-An Artist's Response to the "Unique Status" of Postcolonial Human Remains in Museums.' In: Edward Juler and Alistair Robinson (eds.), Post-Specimen: Interobjective Encounters in Art, Science and Museology. Bristol: Intellect Books, forthcoming, 2020. E-mail: wildgoose@janewildgoose.co.uk.

\section{NOTES}

1 Francis, Doris, Leonie Kellaher and Georgina Neophytou. The Secret Cemetery. Oxford \& New York: Berg, 2005 (20).

2 Idem (21).

3 Idem (23-24).

4 Curious 2013. Curated by Jane Millar, West Norwood Cemetery 22 June-28 July 2013. See: Culture24 Reporter. 'Exhibition preview: Curious-A Site-Specific Art Trail in West Norwood Cemetery, West Norwood Cemetery, London, until July 28 2013.' 'Culture24: art history science,' 26 June 2013, https://www.culture24.org.uk/art/art441080. Date accessed: 15 September 2019.

5 'Maddick Mausoleum.' The Mausolea \& Monuments Trust, http://www.mmtrust.org. uk/mausolea/view/288/Maddick_Mausoleum. Date accessed: 6 September 2019.

6 Worpole, Ken. Last Landscapes: The Architecture of the Cemetery in the West. London: Reaktion Books, 2003 (104).

7 At the time of its opening West Norwood Cemetery was known as the South Metropolitan Cemetery.

8 It is a legal requirement that burials in local authority cemeteries, and elsewhere, must be suitably registered and the records kept safely 'in accordance with the provisions of the Registration of Burials Act 1864,' see: DCA (Department for Constitutional Affairs) Guide for Burial Ground Managers. London: DCA, 2005 (9).

9 Harrison, Robert Pogue. The Dominion of the Dead. Chicago: University of Chicago Press, 2003 (xi).

10 Taylor, Mark C. and Dietrich Christian Lammerts. Grave Matters. London: Reaktion Books, 2002 (23) (italics in original).

11 Doelp, Carol Benner. The Art of French Beaded Flowers: Creative Techniques for Making 30 Beautiful Blooms. New York: Lark Books, 2005 (11); also see: Nathanson, Virginia. The Art of Making Bead Flowers and Bouquets. New York: Hearthside Press, 1967. The immortelle was donated to The Wildgoose Memorial Library collection by the artists Spring Hurlbut and Arnaud Maggs in 2006.

12 According to the first published catalogue of the Hunterian Museum's osteological collection, 'It has been said that in his last moments he [Byrne] expressed an earnest desire that his $[\ldots]$ remains might be sunk out at sea; but if such were his wish, it was never fulfilled, as Mr. Hunter obtained his body before interment of any kind had taken place.' Catalogue of the Contents of the Museum of the Royal College of Surgeons in London. 
Part III. Comprehending the Human Comparative Anatomy. London: Francis Ware, 1831 (3).

13 Wildgoose, Jane. 'Collecting and Interpreting Human Skulls and Hair in Late Nineteenth-Century London: Passing Fables E् Comparative Readings at The Wildgoose Memorial Library; An artist's response to the DCMS Guidance for the Care of Human Remains in Museums (2005).' PhD diss., Kingston University London, 2015.

14 Human Tissue Act 2004 Chapter 30: Section 47. Power to De-Accession Human Remains. London: HMSO, 2004 (29-30).

15 Department for Culture, Media and Sport, Guidance for the Care of Human Remains in Museums. London: DCMS, 2005 (7-8).

16 Idem (8).

17 For a detailed overview of the history of racial 'science' and its relationship with collecting human remains (especially human skulls) see for instance: Douglas, Bronwen. 'Climate to Crania: Science and the Racialization of Human Difference,' and Turnbull, Paul. 'British Anthropological Thought in Colonial Practice: the appropriation of Indigenous Australian bodies, 1860-1880.' In: Douglas, Bronwen and Chris Ballard (eds.), Foreign Bodies: Oceania and the Science of Race 1750-1940. Canberra: Australian National University E. Press, 2008 (35-98; 205-228).

18 For a discussion of my work with human hair and commemoration of the dead, see: Wildgoose, Jane. "Ways of Making with Human Hair and Knowing How to "Listen" to the Dead.' West $86^{\text {th }}$ : A Journal of Decorative Arts, Design History and Material Culture 23:1 (Spring/Summer 2016) (79-101).

19 Sheumaker, Helen. Love Entwined: The Curious History of Hairwork in America. Philadelphia: University of Pennsylvania Press, 2007 (123, 119).

20 Ireland, John. Hogarth Illustrated. Vol. I. London: J. \& J. Boydell, 1793 (cxi).

21 United Nations. 'United Nations Declaration on the Rights of Indigenous Peoples.' United Nations Department of Social and Economic Affairs: Indigenous Peoples, March 2008, Article 12.1, 6, https://www.un.org/development/desa/indigenouspeoples/declaration-on-the-rights-of-indigenous-peoples.html. Date accessed: 15 September 2019.

22 Worpole, Ken, 2003 (114-15).

23 Ruth Richardson, email to author, 21 September 2014. (Capitalization in original.)

24 Kay Syrad, letter to author, 13 October 2014.

25 Sarah van Riemsdijk, email to author, 20 October 2014.

26 See for instance: Pickering, Michael and Phil Gordon. 'Repatriation: The End of the Beginning.' In: Des Griffin and Leon Paroissien (eds.), Understanding Museums: Australian Museums and Museology. Canberra: National Museum of Australia, 2011, published online at https://nma.gov.au/research/understanding-museums/MPickering_PGordon_2011.html, ISBN 978-1-876944-92-6; for insight into the debate in the USA see: Dumont, Clayton Jnr. 'Dead Family or Archaeological Collections?: On the Significance of Native Dead.' Race, Gender Eं Class 9:2 (2002) (8-31); concerning debate in the UK see Brown, Pete. 'Us and Them: Who Benefits from Experimental Exhibition Making?' Museum Management and Curatorship 26:2 (May 2011) 129-148; Jenkins, Tiffany. "Who are we to Decide?" Internal Challenges to Cultural Authority in the Contestation over Human Remains in British Museums.' Cultural Sociology 6:4 (July 2012) (455-470), published online 12 July, accessed July 21, 2018, http://cus.sagepub.com/content/ early/2012/05/15/1749975512445432 and Jenkins, Tiffany. Contesting Human Remains in Museum Collections: The Crisis of Cultural Authority. New York \& Abingdon: Routledge, 2014.

27 For discussion about the impact that learning about this historical context had on my research and practice, while working on a commissioned report on the human remains collection at a major London museum, see: Wildgoose, Jane. 'Post-Specimens and 
Present Ancestors: Passing Fables and Comparative Readings at The Wildgoose Memorial Library-An Artist's Response to the Status of Postcolonial Human Remains in Museums.' In: Ed Juler and Alistair Robinson (eds.), Post-Specimen: Interobjective Encounters in Art, Science and Museology. Bristol: Intellect Books, forthcoming, 2020.

28 Harrison, Robert Pogue, 2003 (x).

29 Idem (xi). 